\title{
Demonstrating an integrated pest management strategy in autumn-sown wheat to arable farmers
}

\author{
A. Horrocks ${ }^{1}$, M.M. Davidson ${ }^{1}$, D.A.J. Teulon ${ }^{1}$ and P.A. Horne ${ }^{2}$ \\ ${ }^{1}$ The New Zealand Institute for Plant E Food Research Limited, Private Bag 4704, \\ Christchurch 8140, New Zealand \\ ${ }^{2} I P M$ Technologies Pty Ltd, P.O. Box 560, Victoria, Australia \\ Corresponding author: Abie.Horrocks@plantandfood.co.nz
}

\begin{abstract}
Six crops of autumn-sown wheat managed under integrated pest management (IPM) were compared to six adjacent crops grown under the participating farmers' current pest management practices in demonstration trials in Canterbury during the 2008-09 and 2009-10 seasons. Farmer training with a focus on monitoring and beneficial predator identification was carried out. The presence and abundance of key pests and diseases (slugs, aphids, yellow dwarf virus (YDV)) and beneficial predators was determined. Carabid beetles and other beneficial insects capable of contributing to pest control were present in the arable cropping systems. There was an increasing trend in the number of beneficial organisms, a reduction in pests and a 50\% reduction in the number of insecticides applied in the IPMmanaged crops. There were negligible YDV and crop yield differences between the two approaches. IPM adoption at these farms was very high after these participatory trials.
\end{abstract}

Keywords integrated pest management, wheat, arable, beneficial predators, carabids.

\section{INTRODUCTION}

Integrated pest management (IPM) is an approach to pest and disease control that maximises biological and cultural pest and disease control practices with the use of selective pesticides when necessary (Horne \& Page 2008). In New Zealand there are several examples of successful IPM programmes including the welldocumented and exemplar pipfruit (Walker et al. 2009) and outdoor tomato programmes (Cameron et al. 2009), which have both led to significant reductions in insecticide use. Most examples of IPM worldwide are from intensive horticulture, but it is possible to apply the same principles to arable crops (Horne \& Page 2008; Horne et al. 2008). The introduction of biological control agents has been successful in controlling the rose grain aphid in cereal crops in Canterbury, New Zealand (Farrell \& Stufkens 1990, Stufkens \& Farrell 1987). Historically, late planting (after mid-May) of autumn cereal crops to avoid peak aphid flights has been successful in reducing aphid infestation and virus infection (Farrel \& Stufkens 1992). However, in recent years there has been a trend for earlier sowing (from early April) of autumn cereal crops so that crops are emerging during peak aphid flights (Bicknell et al. 2000) with greater reliance on insecticide applications to protect such crops from aphids and hence viruses. Increased use of broad-spectrum insecticides for aphid control 
can disrupt beneficial predator populations, such as carabid beetles, and lead to outbreaks of other pests, such as slugs, in succeeding crops.

Farmer participatory trials are one of the best means of gaining adoption of IPM and other changes in practice (Dent et al. 2003; Murray 2000). The purpose of this study was to demonstrate the feasibility of enhancing the adoption of IPM using farmer participatory trials with a small group of arable farmers in Canterbury, New Zealand. The presence and abundance of key pests and diseases (slugs, aphids and viruses) and beneficial predators (carabid beetles, parasitic wasps, lacewings, ladybirds and hoverflies) was established in six pairs of IPM and conventionally-managed autumn-sown wheat crops over the 2008-09 and 2009-10 seasons. Crop yields and YDV infection levels were also compared.

\section{MATERIALS AND METHODS \\ Sites}

Six sites with paired autumn-sown wheat crops under IPM and conventional managed pest and disease control were selected (Table 1). There were three paired crops in the 2008-09 season and three paired crops in the 2009-10 season.

\section{IPM and conventional pest management strategies}

'Conventional' wheat crops were treated with insecticides and molluscicides in accordance with the farmer's standard practice of 2008 (Table 3). This included imidacloprid seed dressing in most cases and at least one application of lambda-cyhalothrin (Karate ${ }^{\circledR}$ ), a treatment that a recent phone survey indicated to be the most commonly used aphicide (van Toor \& Teulon 2007). Selective or broad-spectrum molluscicides were also applied in accordance with current farmer practise.

'IPM' wheat crops had selective insecticides and molluscicides applied only when monitoring indicated they were necessary. In general, monitoring techniques that could be implemented by farmers were used (see below). Decisions on molluscicide use were made based on paddock slug history, monitoring results and moisture levels. Only selective molluscicides, such as EDTA or metaldehyde-based baits, were recommended rather than broad-spectrum methiocarb molluscicides, which can kill carabid beetles through secondary poisoning (Langan et al. 2004). Several species of cereal aphids are responsiblefor transmittingYDV (Rhopalosiphum padi, R. maidis, R. insertum, Metopolophium dirhodum, Sitobion miscanthi and/or S. nr. fragariae), a major cause of cereal losses in New Zealand (Farrel \& Stufkens 1992). All autumnsown wheat crops had an imidacloprid seed dressing to minimise YDV spread through to the start of tillering (growth stage $21=$ GS21) (Stufkens et al. 2003). However, plants are thought to be at risk until GS31 (Thackray et al. 2005). Consequentially, aphid tolerance levels fell into two categories. The first was a low tolerance period between the start of tillering and GS31. Selective aphicides, such as pirimicarb (i.e. Pirimor $\left.{ }^{\circledR}\right)$, were recommended over this period if aphids were found in the crop. Once GS31 was reached, a higher tolerance for aphids was endorsed and aphid incidence was considered only in relation to beneficial predators.

Table 1 Details of the autumn-sown wheat crops in the participatory trial.

\begin{tabular}{llccll}
\hline Site & Location & IPM area (ha) & Conventional area (ha) & Sowing date & Tillage \\
\hline A & Waimate & 12 & 12 & 28 April 2008 & Plough \\
B & Waimate & 12 & 12 & 29 April 2008 & Direct drill \\
C & Ashburton & 12 & 12 & 8 May 2008 & Plough \\
D & Waimate & 11 & 11 & 23 April 2009 & Plough \\
E & Waimate & 8 & 3 & 5 May 2009 & Plough \\
F & Ashburton & 12 & 12 & 5 June 2009 & Plough \\
\hline
\end{tabular}


Farmers were trained to use simple monitoring techniques to identify pests and beneficial predators, and were involved in the monitoring and decisionmaking as much as possible. Whether or not a spray was applied depended on the farmer and the decision with which he was most comfortable. Each farmer was encouraged to develop guidelines to suit their experience levels and circumstances.

Applications of all insecticides and molluscicides were done by the collaborating farmers. All other inputs, such as fungicides and herbicides, were used in accordance with current farmer practice. Yield estimations were made at harvest by farmers using yield monitoring equipment in the combine harvesters.

\section{Slug and carabid beetle monitoring}

Slug activity was monitored using plywood tiles $(29 \times 29 \mathrm{~cm})$. Five tiles, $10 \mathrm{~m}$ apart, were placed within the crop, at least $30 \mathrm{~m}$ from crop margins. Slug monitoring was initiated in the month prior to crop sowing (Table 1) and continued at 1-3 week intervals until GS31 and then at 3-4 week intervals until harvest. A record was made of the number and species of all slugs found under tiles at each monitoring and these slugs were removed.

Carabid beetle activity was monitored using pitfall trapping. Four traps were inserted within the crop (alongside four of the five slug tiles) with the top of each trap flush with the soil surface. These were half-filled with diluted antifreeze as a preservative. Pitfall trap monitoring was also initiated in the month prior to crop sowing date (Table 1) and continued as described for slug traps.

Baseline slug and carabid beetle monitoring was undertaken on three dates before implementing different pest and disease management approaches, and was completed by February 2008.

\section{Monitoring aphids and beneficial insects}

A yellow sticky trap on a $60 \mathrm{~cm}$ bamboo stake was installed next to the first slug tile to give an indication of aphid and aphid predators (such as parasitic wasps (Aphidiinae)) present within the crop. These were installed a month before the crop sowing date (Table 1), checked at each monitoring round and replaced as needed. The pitfall traps, described above, also caught other predators within the crop and if aphids were present they could be seen floating on the surface of the liquid. Once the crop had emerged direct visual aphid and aphid predator searches of plant stems and leaves were carried out at each monitoring round on two plants randomly chosen within a $5 \mathrm{~m}$ range of each slug tile (totalling 10 plants per time per crop). All aphids found (from the pitfall traps, yellow sticky traps and direct searches) within the crop prior to the plants reaching GS31 (i.e. while the crop is at risk, Thackray et al. 2005) were assumed to be potential virus carriers.

\section{Yellow dwarf virus (YDV) monitoring}

Wheat crops were scored for YDV symptoms in early flowering (GS50-79). The number of flag leaves showing characteristic YDV symptoms (yellow and/or red coloration; D'Arcy 1995) were counted, and the percentage of YDV incidence was estimated visually from each of about eighteen $1 \mathrm{~m}^{2}$ quadrats. At least six quadrats (>40 $\mathrm{m}$ apart) were sampled from three rows at each site. Rows were at least $40 \mathrm{~m}$ apart and $20 \mathrm{~m}$ from the field margin.

\section{Statistical method}

Data were analysed using simple one way ANOVA. There was evidence that some data required a natural log transformation due to lack of homogeneity. Analyses were carried out using GenStat v.11. Figures were produced in SigmaPlot v.10.

\section{RESULTS}

Baseline monitoring showed that predatory carabid beetles were present at most sites prior to implementing the different management systems. Numbers were similar between intended IPM and intended conventional crops $(\mathrm{P}=0.596)$, although numbers were highly variable between farms. In total, 235 carabid beetles were collected in baseline pitfall trapping. The most abundant species was Holcaspis angustulus (88.5\%), followed by Metaglymma moniliferum (11.5\%). 
In total, 1332 carabid beetles were collected in the pitfall traps during the actual trials, 914 from the IPM crops and 418 from the conventional crops during both years. In 2008-09 there were 38 monitoring rounds at sites $\mathrm{A}, \mathrm{B}$ and $\mathrm{C}$ and in 2009-10 there were 35 monitoring rounds at sites $\mathrm{B}, \mathrm{C}$ and $\mathrm{D}$. The most abundant species was $H$. angustulus (78.2\%) followed by M. moniliferum (21.5\%). Five unknown carabid beetles were found at site E and were identified by Philip Howe from the South Canterbury Museum as an undescribed species of Mecodema. Overall, there was a trend for higher numbers of carabid beetles in the IPM crops compared with the conventional crops, although the difference was not statistically significant $(\mathrm{P}=0.126)$. However, there were significantly $(\mathrm{P}=0.043)$ more beetles in the IPM crops compared with the conventional crops for the 2 month period (3 monitoring dates) after lambda-cyhalothrin was applied to the conventional crop (Figure 1).

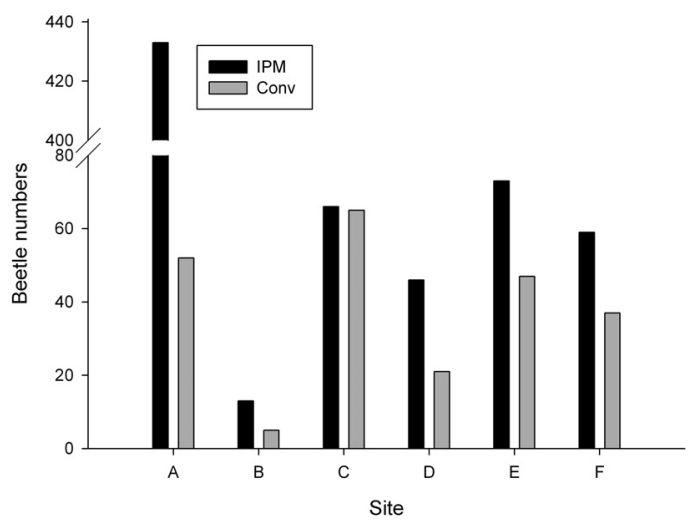

Figure 1 Carabid beetle numbers in IPM and conventional crops for the 3 monitoring dates combined after lambda-cyhalothrin had been applied to the conventional crops.

In total, 145 slugs were recorded from the slug traps over the trial. The most abundant species was Derocerus reticulatum (57.4\%), followed by Derocerus panormitanum (41.4\%) and then Milax gagates (1.2\%). Molluscicides were only applied at site B (a single application of Metarex ${ }^{\circledR}$, a selective molluscicide, was applied after drilling). Overall slug numbers tended to be higher in the conventional crops than the IPM crops (Figure 2), although differences were not statistically significant $(\mathrm{P}=0.123)$.

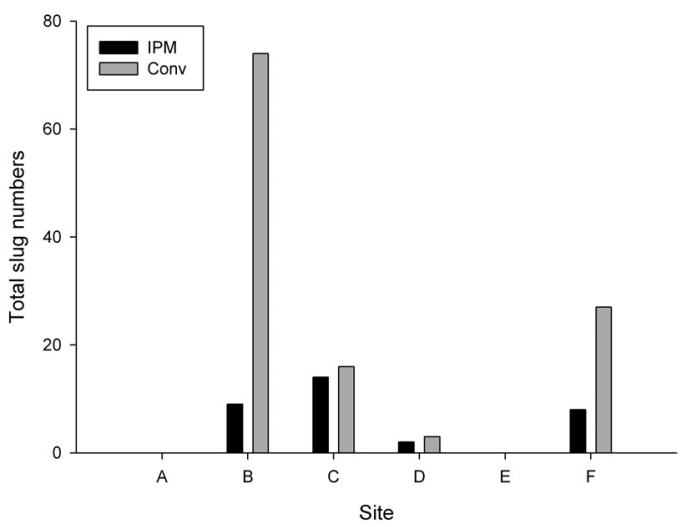

Figure 2 Total slug numbers found in the IPM and conventional crops for 2008-09 (38 monitoring rounds, sites A, B and C) and 200910 (35 monitoring rounds, sites D, E and F).

Monitoring (pitfall trap, sticky trap and direct search) of aphids and aphid predators, other than carabid beetles, confirmed aphids and seasonal influxes of beneficial predators, such as parasitic wasps (Aphidiinae), lacewings (Mircomus tasmaniae (Walker), ladybirds (Coccinellidae) and hoverfly (Syrphidae).

There were negligible yield differences between the IPM and conventionally managed crops $(\mathrm{P}=0.391)$ for both the early- and late-sown wheat crops (April-June). Yields ranged from 9-12 $\mathrm{t} / \mathrm{ha}$ between sites. Likewise, the YDV assessments carried out at the flag leaf stage for both the 2008-09 and 2009-10 growing seasons found there to be negligibleYDV and no differences between treatments $(\mathrm{P}=0.886)$ at all sites for both seasons (Table 2). The highest YDV value of $1.7 \%$ was in an early-sown conventionally-managed wheat and was well below the $>5 \%$ economic threshold (Teulon et al. 1999).

All crops were seed-treated with imidacloprid except for one conventional crop. However, only one foliar insecticide application was made to IPM crops combined compared to nine to conventional crops combined (Table 3 ). 
As collaborating farmers learnt more about the biological, cultural and selective chemical management options available to them they started to utilise IPM across larger areas of their arable rotations (Table 4), becoming increasingly reluctant to use broad-spectrum insecticides.

\section{DISCUSSION}

The aims of this project were (i) to test the applicability of the extension model to influence adoption of IPM practices; (ii) to demonstrate to farmers that adoption of such practices did not cause them to suffer yield losses due to

Table 2 Estimates of YDV infection (\%) for 2008-09 and 2009-10 growing seasons.

\begin{tabular}{lllc}
\hline Farm & Sowing date & IPM & Conventional \\
\hline A & 28 April 2008 & 0.11 & 0.03 \\
B & 29 April 2008 & 0 & 0.11 \\
C & 8 May 2008 & 0.22 & 0.11 \\
D & 23 April 2009 & 0.30 & 1.70 \\
E & 5 May 2009 & 0.98 & 0.20 \\
F & 5 June 2009 & 0.32 & 0.05 \\
\hline
\end{tabular}

Table 3 Insecticides used on the IPM and conventionally-managed crops for the six autumn sown wheat crops.

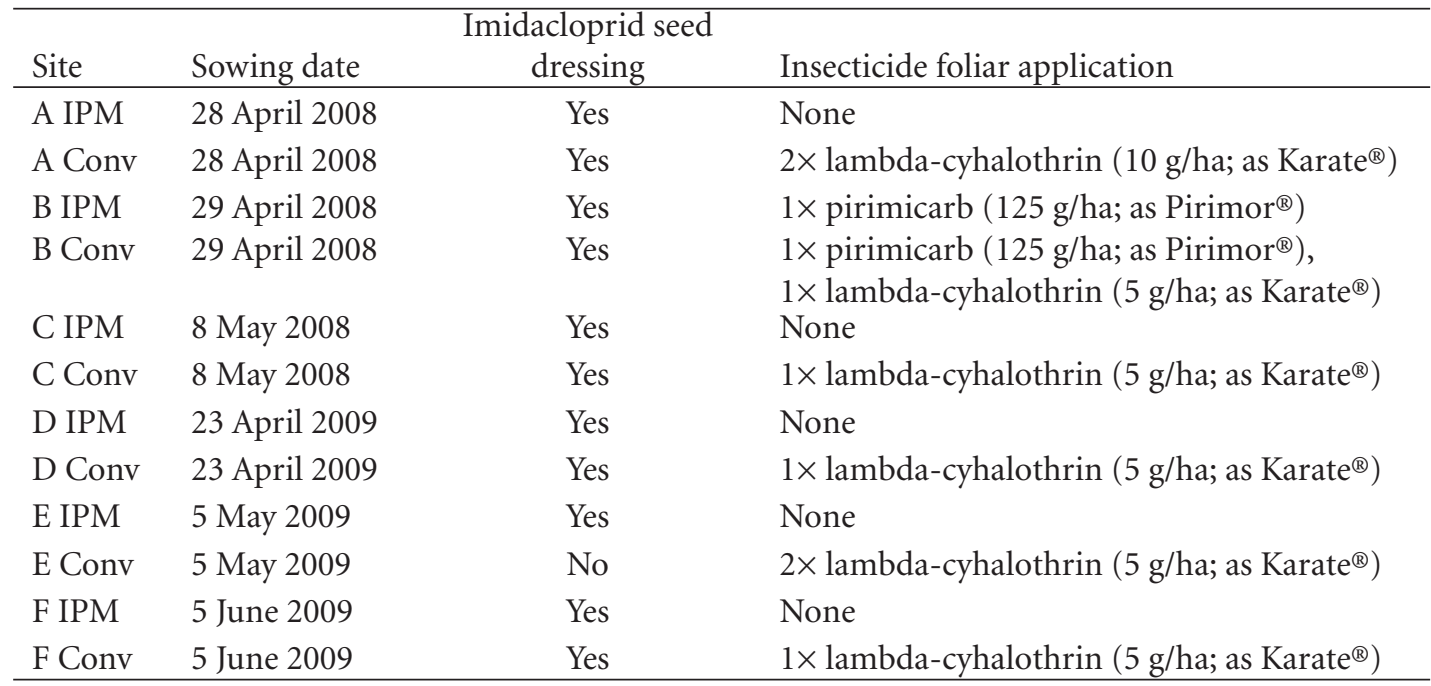

Table 4 Implementation of IPM in the arable rotations of the collaborating farms.

\begin{tabular}{llll}
\hline Site & $2008-09$ & $2009-10$ & $2010-11$ \\
\hline A & $1 / 2$ a paddock & $50 \%$ of farm & $100 \%$ of farm \\
B & $1 / 2$ a paddock & $50 \%$ of farm & $100 \%$ of farm \\
C & $1 / 2$ a paddock & $50 \%$ of farm & $80-100 \%$ of farm \\
D & 1 paddock & $80 \%$ of farm & $100 \%$ of farm \\
E & 1 paddock & $80 \%$ of farm & $100 \%$ of farm \\
F & $1 / 2$ a paddock & $50 \%$ of farm & $80-100 \%$ of farm \\
\hline
\end{tabular}


unacceptable pest levels (or insect-vectored viruses); and (iii) that beneficial insects were present that could help reduce pest populations if not disrupted by broad-spectrum insecticides. All three aims of this project were met successfully.

For the IPM crops, farmers were trained to use simple monitoring techniques to identify pests, parasitoids and beneficial predators, and were involved in the monitoring and decision making. Decisions were based on the number of pests compared to the number of predators. Whether or not sprays were applied depended on the farmer and the decision he was comfortable making. Research in Australia has shown that as farmers start to value the contributions that beneficial insects make to pest management they become more confident and no longer feel the need to 'spray an insecticide just in case' (Horne et al. 2008).

The main difference in pest management between the conventional and IPM approaches was that at least one synthetic pyrethroid was applied to each of the conventional crops (Table 3 ). Monitoring over the two growing seasons confirmed the presence of beneficial carabid beetles at all sites, but there were significantly less in the conventional crops subsequent to applications of lambda-cyhalothrin (Figure 1). Site B had the fewest carabid beetles and the most slugs (Figure 2) over the duration of the monitoring period and was the only site that applied a selective molluscicide. This may be related to the fact that this farmer direct drills, which can result in slug problems (Glen \& Symondson 2003), and that he had relied heavily in the past on methiocarb molluscicides, a broad-spectrum chemicals that kills carabid beetles through secondary poisoning (Langan et al. 2004).

Carabid beetles are polyphagous predators, feeding on a range of pests, including aphids and slugs (Kromp 1999), and consequently can contribute to natural pest suppression. While the extent to which they contribute to slug control in crops is hard to quantify, research in the UK has found that beetle predation of slugs is not merely opportunistic (Bohan et al. 2000) and that some species of carabid aggregate to areas of high slug numbers implying preferential feeding on slugs (Symondson et al. 1996). Recent research in Australia has demonstrated that carabid beetles have a massive impact on slug populations (Nash et al. 2008). It is possible that the trend of higher carabid beetle numbers in the IPM crops may be contributing to the lower slug numbers in these crops (Figure 2). The relatively long generation times of carabid beetles (1-2 years) means that the impact of a single synthetic pyrethroid may result in reduced populations.

Aphid monitoring, using sticky traps, pitfall traps and direct search methods, determined that 2008-09 and 2009-10 were low risk BYDV years and consequently few selective insecticide recommendations were made. Additionally, the number of cereal-inhabiting aphids caught in nearby $7.5 \mathrm{~m}$ high suction traps at Lincoln (central Canterbury) and St Andrews (South Canterbury) were relatively low indicating that in these years there was low risk of YDV infection (D.A.J. Teulon, unpublished data). It remains to be seen how well the IPM approach works in a year of high aphid flight activity and hence high virus pressure.

The negligible YDV differences between the IPM and conventional crops (Table 2), $50 \%$ reduction in the number of insecticides applied in the IPM managed crops (Table 3) and the negligible yield differences contributed to the farmers involved in this project becoming enthusiastic users of IPM with a keen interest to preserve the beneficial predators in their cropping systems. Based on the experience of IPM extension and uptake programmes in Australia, it takes 3 years of support before farmers undergo a mindset change in how they approach pest management (Horne et al. 2008).

This project has demonstrated that an IPM approach can allow arable farmers in New Zealand to obtain good control of pests without compromising quality of pest management in the two years of this study. It has clearly demonstrated that the method of using farmer-participatory trials can deliver a change in practice (Table 4). However, future projects need to provide training and support to both farmers and agricultural 
service providers for the widespread adoption of this approach to succeed.

\section{ACKNOWLEDGEMENTS}

We thank the growers, Colin Hurst, Roger Small, Guy Wigley, Brian Leadley and David Ward, for their ongoing enthusiasm; the Foundation for Arable Research and the Ministry of Agriculture and Forestry's Sustainable Farming Fund for their support of the project, and PGG Wrightson, Elliot Chemicals, Syngenta and Bayer for their financial and product contributions. We also thank Esther Meenken for her statistical assistance and Philip Howe for his carabid beetle identification expertise.

\section{REFERENCES}

Bicknell K, Greer G, Teulon DAJ 2000. The value of forecasting BYDV in autumn sown cereals. New Zealand Plant Protection 53: 87-92.

Bohan DA, Bohan AC, Glen DM, Symondson WOC, Wiltshire CW, Hughes L 2000. Spatial dynamics of predation by carabid beetles on slugs. Journal of Animal Ecology 69: 367379.

Cameron PJ, Walker GP, Hodson AJ 2009. Trends in IPM and insecticide use in processing tomatoes in New Zealand. Crop Protection 28: 421-427.

D'Arcy CJ 1995. Symptomology and host range of barley yellow dwarf. In: D’Arcy CJ, Burnett PA ed. Barley yellow dwarf 40 years of progress. APS Press, St Paul, Minnesota. Pp. 9-28.

Dent DR, Holderness M, Vos JGM2003.Integrated pest management at $\mathrm{CAB}$ international. In: Maredia KM, Dakouo D, Mota-Sanchez D ed. Integrated pest management in the global arena. CABI Publishing, UK. Pp. 493-499.

Farrell JA, Stufkens MW 1990. The impact of Aphidius rhopalosiphi (Hymenoptera: Aphidiidae) on populations of the rose grain aphid (Metopophium dirhodum) (Hemiptera: Aphididae) on cereals in Canterbury, New Zealand. Bulletin of Entomological Research 80: 377-383.
Farrell JA, Stufkens MW 1992. Cereal aphid flights and barley yellow dwarf virus infection of cereals in Canterbury, New Zealand. New Zealand of Crop and Horticultural Science 20: 407-412.

Glen DM, Symondson WOC 2003. Influence of soil tillage on slugs and their natural enemies. In: Titi AE ed. Soil tillage in agroecosystems. CRC Press Inc. USA. Pp. 207-227.

Horne PA, Page J 2008. Integrated Pest Management for crops and pastures. CSIRO Landlinks Press, Australia. 119 p.

Horne P, Page J, Nicholson C 2008. When will IPM strategies be adopted? An example of development and implementation of IPM strategies in cropping systems in Victoria. Australian Journal of Experimental Agriculture 48: 1601-1607.

Kromp B 1999. Carabid beetles in sustainable agriculture: a review on pest control efficacy, cultivation impacts and enhancement. Agriculture, Ecosystems \& Environment 74(1/3): 187-228.

Langan AM, Taylor A, Wheater CP 2004. Effects of metaldehyde and methiocarb on feeding preferences and survival of a slug predator (Pterostichus melanarius (F.): Carabidae, Pterostichini). Journal of Applied Entomology 128: 51-55.

Murray P 2000. Evaluating participatory extension programs: challenges and problems. Australian Journal of Experimental Agriculture 40: 519-526.

Nash MA, Thomson LJ, Horne PA, Hoffmann AA 2008. Notonomus gravis (Chaudoir) (Coleoptera: Carabidae) predation of Deroceras reticulatum Muller (Gastropoda:Agriolimacidae), an example of fortuitous biological control. Biological Control 47: 328-334.

Stufkens MW, Farrell JA. 1987. Establishment of Aphidius rhopalosiphi, a parasitoid of the rosegrain aphid in New Zealand. Proceedings of the $40^{\text {th }}$ New Zealand Weed and Pest Control Conference: 15-18. 
Stufkens MAW, James DE, Wallace AR 2003. Imidacloprid (Gaucho ${ }^{\circledast}$ ) persistence on autumn-sown wheat. Crop \& Food Research Confidential Report No. 968. New Zealand Institute for Crop \& Food Research Limited, Christchurch, New Zealand.

Symondson WOC, Glen DM, Wiltshire CW, Langdon CJ, Liddell JE 1996. Effects of cultivation techniques and methods of straw disposal on predation by Pterostichus melanarius (Coleoptera: Carabidae) upon slugs (Gastropoda: Pulmonata) in an arable field. Journal of Applied Ecology 33(4): 741753.

Teulon DAJ, Stufkens MAW, Nicol D, Harcourt SJ 1999. Forecasting barley yellow dwarf virus in autumn-sown cereals in 1998. Proceedings of the 52nd New Zealand Plant Protection Conference: 187-191.
Thackray DJ, Ward LT, Thomas-Carroll ML, Jones RAC 2005. Role of winter-active aphids spreading barley yellow dwarf virus in decreasing wheat yields in a Mediterraneantype environment. Australian Journal of Agricultural Research 56: 1089-1099.

Van Toor RF, Teulon DAJ 2007. Insecticides used to control aphids transmitting BYDV in autumn sown cereals: a review of their effects on carabid predators of slugs. Crop \& Food Research Confidential Report No. 1907, New Zealand Institute for Crop \& Food Research Limited, Christchurch, New Zealand.

Walker JTS, Park NM, Clothier BE, Manktelow DWL, van den Dijssel CW, Hodson AJ, Barley MJ, Hodson-Kersey LR 2009. Progress in pesticide risk reduction in New Zealand horticulture. New Zealand Plant Protection 62: 321-327. 